\title{
Analysis and Demolition of Some Vaults of the Church of La Peregrina in Sahagún (Spain)
}

\author{
HUERTA Santiago ${ }^{1, a}$ and FUENTES Paula ${ }^{2, b}$ \\ 1,2 School of Architecture, Polytechnic University of Madrid, Madrid, Spain \\ asantiago.huerta@upm.es, b paula.fuentes@gmail.com
}

\begin{abstract}
The Franciscan church of La Peregrina in Sahagún (Spain) was founded in the $13^{\text {th }}$ Century. It has undergone many transformations and additions throughout its history. The most important were carried out in the $17^{\text {th }}$ Century when the church was converted to the Baroque style. The apse vaults were demolished and new timbrel vaults were built hiding the Mudéjar windows. In the nave, the transverse arches that supported the modern roof were also demolished, internal counterforts were built and new barrel timbrel vaults with lunettes, erected. Eventually, an oval dome was built on the transept. Recent restoration work will give the building a new use. The project aims to recover the Mudéjar apse with its windows providing natural light to the presbytery. This involves the demolition of the Baroque vaults above the presbytery (a barrel vault terminated with a semi-dome). The oval dome will lose some buttressing to the side of the apse and an expertise was required to assess the feasibility of the operation. In the present paper the structure of the church will be described and the analysis of the oval dome with and without the presbytery vaults will be explained.
\end{abstract}

Keywords: Masonry, oval dome, tile vault, limit analysis, equilibrium, thin shell

\section{Introduction}

The church of La Peregrina is located on a small hill in the town of Sahagún (León, Spain). The church has undergone various alterations since its construction in the $13^{\text {th }}$ Century. One of the most prominent alterations took place towards the end of the $17^{\text {th }}$ Century, when the Múdejar apse vault was demolished and replaced by a timbrel vault. The transverse arches of the nave were also demolished. A new barrel timbrel vault with lunettes were constructed over the nave, and a new oval dome was built over the transept. At present, a new project aims to recover the Múdejar apse, hidden after the mentioned $17^{\text {th }}$ century alteration. The demolition of the apse vault is required and, therefore, the oval dome over the transept will experience a loss of buttressing. The paper is summary of an expertise written for the architect in charge of the restoration of the church, about the feasibility of the demolition and the eventual measures of consolidation (Huerta et al. 2010).

\section{Historic Study}

La Peregrina church is part of a Franciscan convent founded in Sahagún in 1257, and constructed from 1260. The church was designed to have a single nave with 6 bays and a polygonal apse. Originally, the church was covered with a timber roof resting on transverse arches made of brick, except for the apse, which was covered with a vaulted roof. The Lady chapel is found behind the apse.

To the north of the nave, three chapels were built at a later date. The first chapel is located closest to façade of the church. To the south of the nave, between the transept and the apse, a further chapel was built around the mid $15^{\text {th }}$ century. This chapel is very famous for its geometrical islamic gypsum decorations. The cloister of the convent was built to the south of the nave.

The convent underwent many alterations. The most important intervention took place towards the end of the $17^{\text {th }}$ century. Part of the timber roof had collapsed, and the brick walls were in poor condition. In response to these problems, the transverse arches were demolished and the nave was covered by brick timbrel vaults with lunettes. (This particular type of vault is made of two layers of bricks, set flat with gypsum, and breaking joints, forming one thin shell). The typical thickness is 100 
$\mathrm{mm}$, and were built without centering. On the construction and mechanics of these vaults, see (Huerta 2003).)These vaults were built on added piers, adjacent to the walls, but unconnected to the existing masonry. The transept was covered with an oval dome resting on pendentives. The presbitery was covered with a barrel vault with lunettes terminated by and apsidal dome.
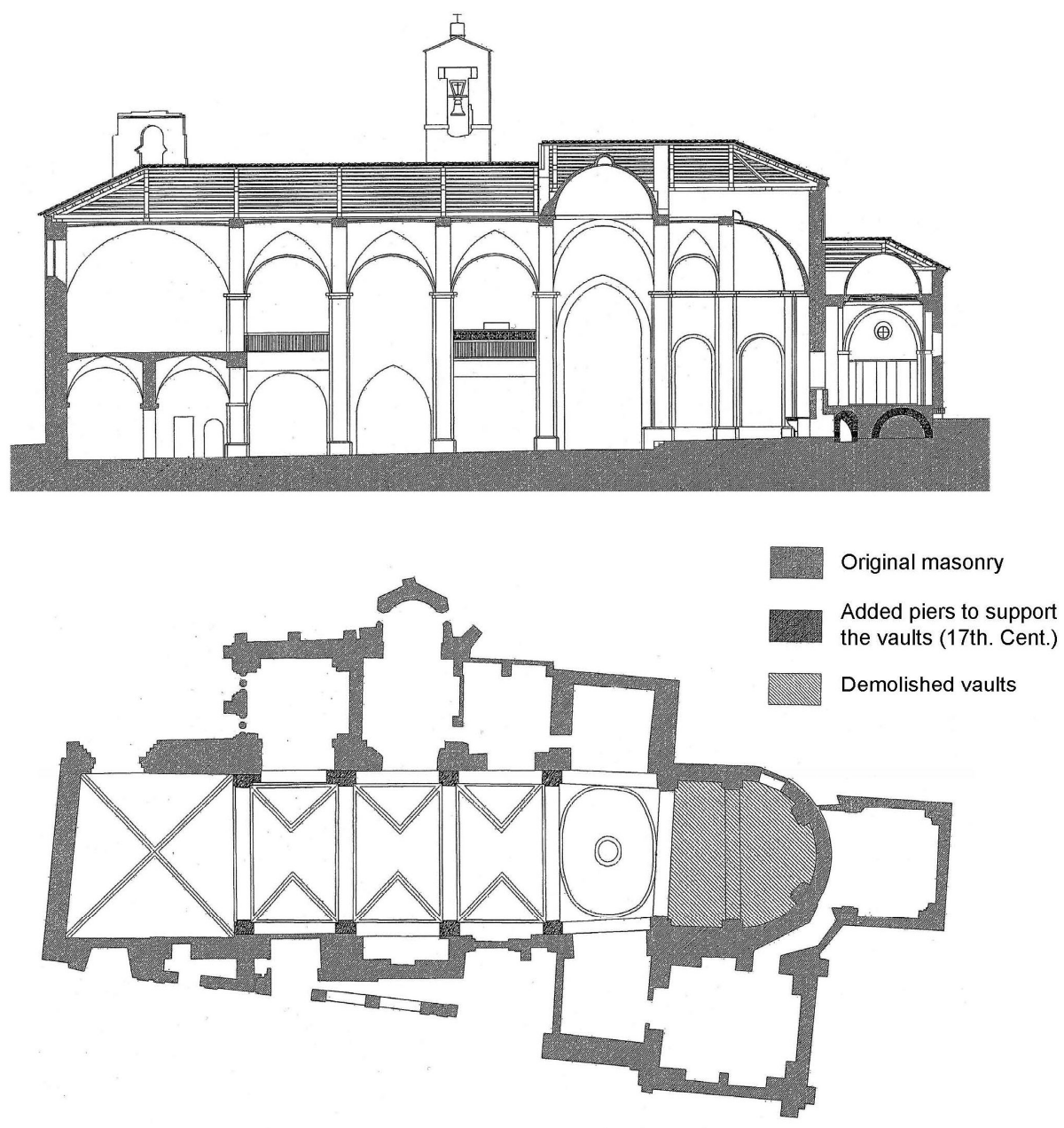

Figure 1: Plan and section views of the church in its current state (drawings by J. R. Solá)
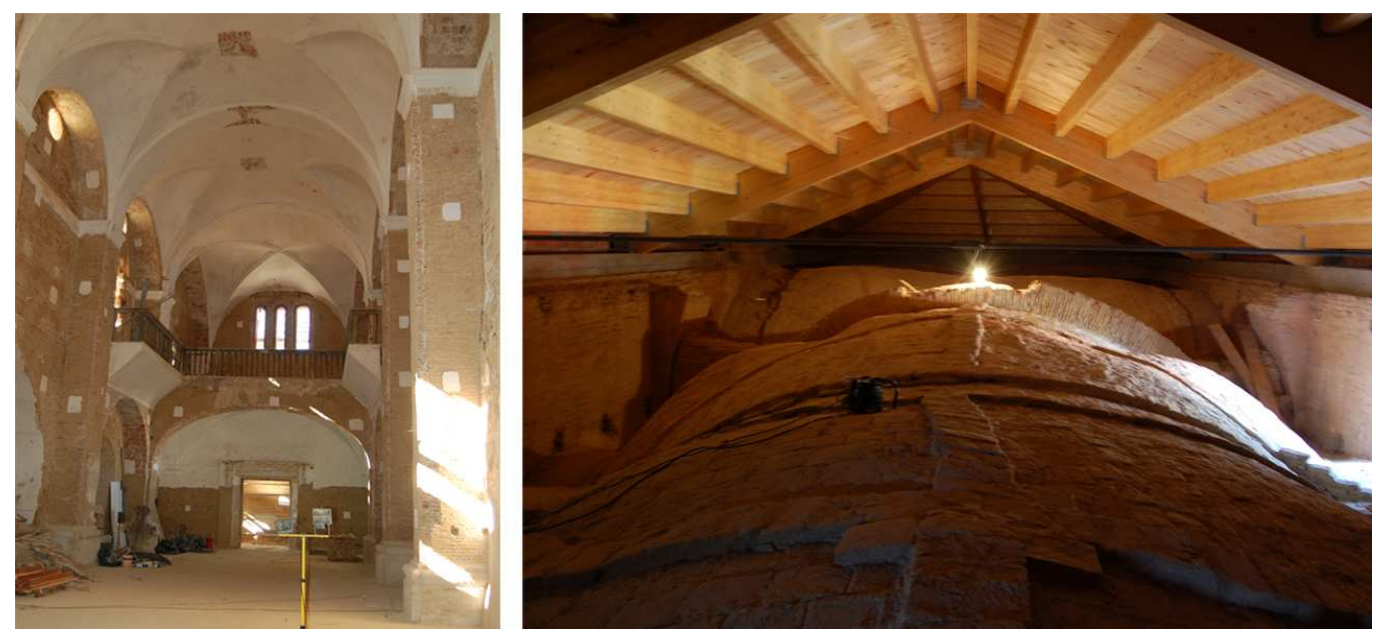

Figure 2: (a) internal view of the nave; (b) extrados of the vaults over the nave 


\section{Geometry of the Oval Dome}

In order to perform a stability study of the masonry, it is necessary to carry out an accurate geometrical survey. The survey was carried out by Dr. Ana López, using a laser total station. With the measured points and a 3D software, Rhinoceros in this particular case, it is easy to interpolate a surface with enough accuracy. The dome over the transept is a timbrel oval dome, two layers thick (approx. $80 \mathrm{~mm}$ in total) and resting on four pendentives built between the four principal arches. The dome has a central oculus. The pendentives are half-foot thick (approx. $140 \mathrm{~mm}$ ), comprised of a number of horizontal layers, built using the technique known as 'false vault'. There is an impost between the dome and the pendentives. The dome, as well as the pendentives, was constructed without the use of centering.

The structure can be clearly distinguished from the extrados. In particular, much of the fill on the two pendentives adjacent to the nave has worn away, showing the transition between the dome and the pendentive (Fig. 3.a). Thanks to this, a very peculiar characteristic has been observed: the dome and the pendentives are part of the same surface. There is no sign of the usual discontinuity at the impost, it is all one single surface (Fig. 3.c). This observation has been confirmed by the geometrical survey.

From underneath, the observer tends to consider the impost as what it usually is, the result of the intersection of two surfaces with different curvature, the tangents to the intrados of the dome at the impost being usually vertical. This is not the case at La Peregrina, where dome and pendentives have a common inclined tangent at the impost. This fact has a very important structural consequence. The shape of the dome and pendentives is such that a compressive membrane equilibrium solution is possible. Therefore, the fill and the abutment walls that are usually built up to $2 / 3$ of the height of the dome are not necessary. (This recommendation was given by Fray Lorenzo in his 1639 treaty and can be observed in almost all hemispherical domes with uniform thickness.) Thus, demonstrating great skill, the master builder of La Peregrina devised a shape that, capable to adapt to a rectangular layout, didn't require the fill and low buttressing walls that would have made the work more expensive and complex. Besides, since the system dome-pendentives forms a unique vault the principal arches receive substantially less weight.

This geometric characteristic greatly simplifies, as will be seen, the problem of the demolition of the vaults over the presbytery.



(a)

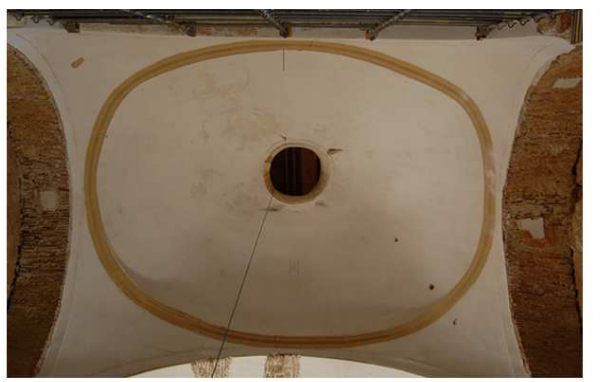

(b)

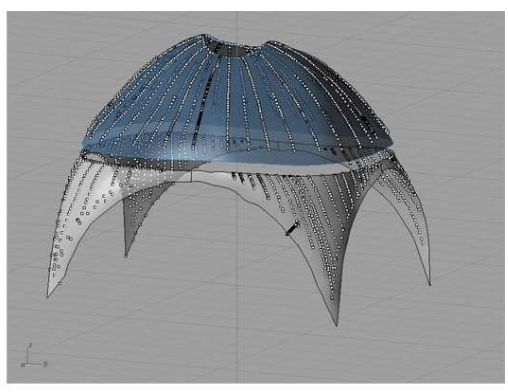

(c)

Figure 3: (a) View of the extrados; (b) View from the inside; (c) Geometry of the dome

The extrados of the dome presents many irregularities. These are due to building without centering and not paying much attention to the continuous variation of the curvature. This becomes evident near the oculus, which forms a warped curve in space (Fig. 3.c). This could perhaps be considered as 'untidy' construction, but the truth is that these irregularities can't be appreciated from the nave (Fig. 3.b), and the builder probably opted to save the excess cost that an accurate definition of the surface would have introduced. Besides, the survey shows that the rectangle of the base is in fact a quadrilateral; the sides that correspond to the nave are almost parallel, but the sides corresponding to the transept are not. This is frequently the case in historic construction, where different conditionings motivated by diverse aspects related in general to the history of the building, don't allow the design 
and construction of perfectly regular layouts. It is the duty of the architect or master builder to hide these imperfections. In the case of La Peregrina, the four pendentives in the corners, the quasi-regular shape of the oval at the impost and, above all, the central oculus projection over a horizontal plane forming a circumference, are symmetries that make the observer believe the shape is regular.

The irregularities in the curvature of the dome could, however, have an important structural effect. Masonry is a no-tension material and, if there were an area in the dome that was concave (looking downwards), that is, positive Gaussian curvature with the main radius of curvature pointing upwards, a local failure could take place. The fact that this has not happened in the centuries the dome has been standing, combined with the absence of cracks on the intrados, is a definite proof that there are no such dangerous local points in the dome of La Peregrina. With the 'digital' version of the geometry, using Rhinoceros again, it is possible to analyze the local curvature, obtaining Gaussian curvature maps. This study has yielded that there are no positive Gaussian curvatures that lead to concavities looking downwards, confirming the facts. Nevertheless, there are some points, mostly coincident with the evident irregularities, where Gaussian curvature is negative. This is not a problem, for a load-bearing arch can still form. Finally, buckling instability does not take place in shells with such a pronounced curvature and small dimension. However, the problem has also been studied.

\section{Weight and Thrust of the Dome}

According to the survey, the total volume of the dome is $4,5 \mathrm{~m} 3$ (for a thickness of $80 \mathrm{~mm}$, that is, two layers of 'flat' bricks). Taking the specific weight $\gamma$ of brick to be between 15 and $17 \mathrm{kN} / \mathrm{m} 3$, the weight of the dome will lay between 67,5 and $76,5 \mathrm{kN}$, that is, between 7 and 8 tons.

Given the small thickness of the dome, it seems reasonable to consider a membrane state to find the principal stresses. In membrane state, all internal stresses are considered to be contained within the intermediate surface, that is, the resultants of the stresses are tangent to the surface. Thus, on the base of the dome there will be a distribution of meridian stress resultants $N_{\varphi}(\mathrm{kN} / \mathrm{m})$ that will be tangent to the edge of the dome. The membrane stress state yields very low stress resultants $N_{\varphi}$ and $N_{\theta}$, which are always in compression. This is due to the fact that the shell does not have a vertical tangent on its edge. The order of magnitude of the stresses in a shell is independent of the thickness, but proportional to the specific weight and to the radius of curvature (Heyman 1977). Taking a maximum radius of curvature $R$ of about $10 \mathrm{~m}$, the stress $\left(\sigma_{\varphi}=\gamma R\right)$ will be of around $170 \mathrm{kN} / \mathrm{m} 2=0,17 \mathrm{~N} / \mathrm{mm}^{2}$. This is a very low stress, as is usually the case for shells subject to dead load.

The tangent at the level of the impost, as can be appreciated from Fig. 3. (c), is not vertical. Therefore, the stress resultants can be decomposed in two components: one vertical and the other horizontal. The average vertical component $V_{a}$ can be obtained dividing the total weight of the dome by the length of the oval on the base, approx. $22 \mathrm{~m}$. Then, $V_{a}=80 / 22=3,65 \mathrm{kN} / \mathrm{m}$ or $36,5 \mathrm{ton} / \mathrm{m}$.

Near the pendentives, the forces are transferred without difficulty because, as said before, there is no discontinuity of the curvature. In the area near the arches, however, some horizontal thrust is generated. This thrust must be counteracted in order to preserve equilibrium in the dome. Currently, the principal arches and the vaults are counteracting this thrust.

When demolishing the vaults over the presbytery, the horizontal component of the dome could lose counteraction in this area. Two points must be risen: 1) the shell is much more rigid than the principal arches and most of the load is transferred through the pendentives; 2) there are small buttressing walls which transmit part of the load to the perimetral walls.

However, even assuming that the shell does transfer all the theoretical horizontal component, this is very small in comparison of the weights of the adjacent elements. For the average inclination of the tangent, the horizontal thrust is approximately $V_{a} / 2$, that is, $H_{a}=1,8 \mathrm{kN} / \mathrm{m}$ or $0.18 \mathrm{ton} / \mathrm{m}$.

The area that does not belong to the pendentive can be calculated to measure nearly $3 \mathrm{~m}$. The principal of the arch, after the demolition of the existing vault, should, then, withstand a horizontal resultant of around $5.40 \mathrm{kN}$ or half a ton. The thickness of the arch is $250 \mathrm{~mm}$ and its width is 670 $\mathrm{mm}$; its weight, therefore, is approx. $2,87 \mathrm{kN} / \mathrm{m}$ (Fig. 4). This weight is enough to transfer the inclined 
thrust of the shell within the arch. Therefore, it seems that the vault of the presbytery could be demolished, even if no structural action was taken.



(a)

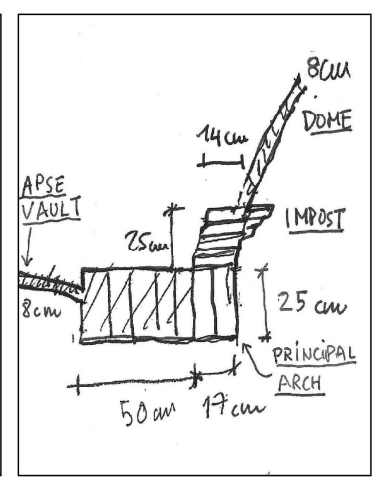

(b)

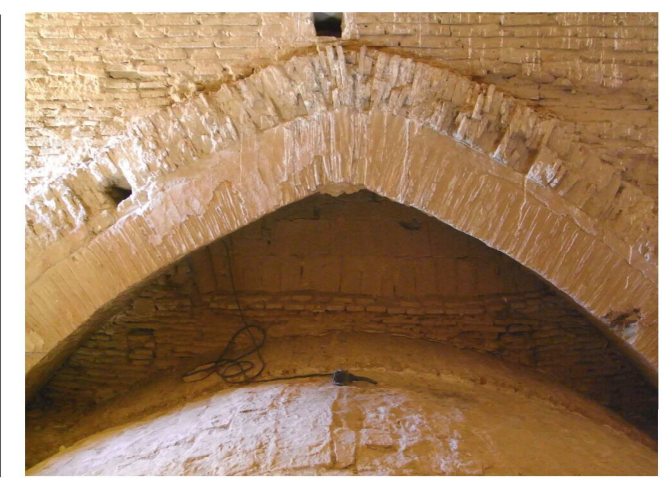

(c)

Figure 4: Construction details of the dome before reinforcement: (a) Sketch of the main elements; (b) section by the principal arch; (c) photograph from the apse vault before demolition

\section{Measures in Preparation for the Demolition of the Dome}

Despite the calculations suggesting the demolition of the dome could be carried out without any additional measures, it was agreed that a number of interventions would be carried out in order to fully guarantee stability.

Two more little abutment walls were added between the extrados of the dome and the wall over the chancel arch. Thanks to being closer to the keystone of the arch, these walls will transfer more of the weight of the shell on to the pendentives. The chancel arch was strengthened by building an over-arch with a thickness of 1 foot $(250 \mathrm{~mm})$ and the same width as the chancel arch $(500 \mathrm{~mm})$, aligned with the adjacent wall. The haunches of this over-arch were filled with good-quality brick masonry of the same thickness (Fig. 5.a); eventually, over the horizontal extrados a horizontal lintel arch with a thickness of $1 / 2$ foot was built. The purpose of this masonry is that the system can act as a flat arch if necessary, transmitting thrusts to the springings, if necessary. A brick wall was also built over the chancel arch, running horizontal from the keystone to the lateral walls. The wall has the height of the top of the impost of the dome (Fig. 5.b). The space between the extrados of the pendentives and the wall was filled. The fill was constructed alternating layers of soil and week lime mortar, tamped down to obtain a suitable consistency. The works concluded with the cleaning and repointing of the buttressing walls of the dome (Fig. 5.c).

Once these measures were implemented, and enough time had been allowed for the curing of the mortar, the work continued with the separation of the vault over the presbytery.



(a)

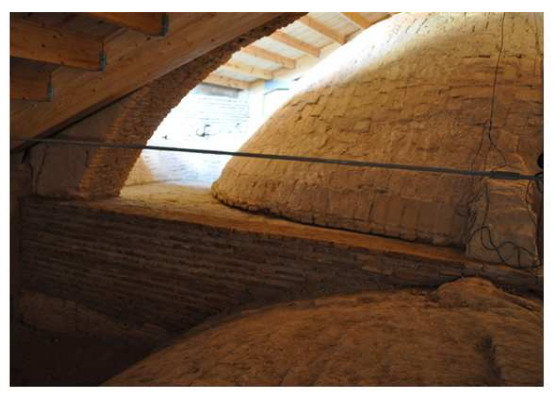

(b)

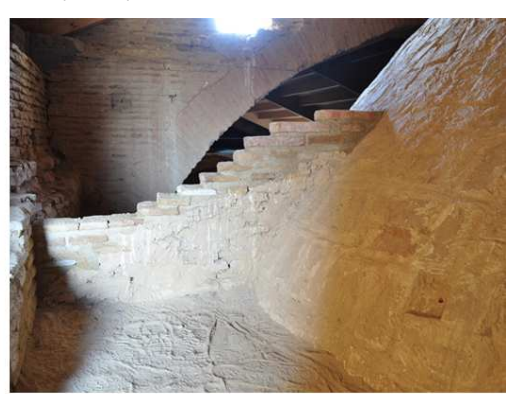

(c)

Figure 5: Preparation of the dome for the demolition. (a) over-arch; (b) wall over the chancel arch and new fill; (c) reparation of the existing abutment walls 


\section{Demolition of the vault}

In order to carry out the demolition of the vault, the first task was to separate it from the oval dome and check there were no movements in the dome. First, a cut through the dome next to the chancel arch was done using a circular saw. The cut run from springing to springing. After observing the state of this cut, a second cut was done parallel to the first one, with a separation of approx. $100 \mathrm{~mm}$. The stretch of vault between the cuts was then demolished (Fig. 6). After the demolition of the narrow stretch, no progress was made on the demolition for a week in order to monitor for any possible movements. No movements were appreciated, and the rest of the vault was demolished.


Figure 6: Sequence of the demolition of the vault.



\section{Conclusions}

The knowledge of the historical constructive system and the confidence and respect for traditional building methods, has allowed to make an intervention both safe and economical. The structural analysis has been made within the frame of Limit Analysis: the Safe Theorem permits the simple equilibrium calculations which were made. In fact, a more 'sophisticated' (maybe using FEM) analysis would not be more precise, as the constitutive equations and the boundary conditions are unknown and unknowable (Heyman 1995, 2008). Safety depends on geometry (Huerta 2004).

Figure 7: The freed apse

\section{References}

[1] Heyman, J (1977). “Equilibrium of Shell Structures.” Oxford: Clarendon Press.

[2] Heyman, J (1995). "The Stone Skeleton. Structural Engineering of Masonry Architecture." Cambridge: Cambridge University Press.

[3] Heyman, J (2008). “Basic Structural Theory. ” Cambridge: Cambridge University Press.

[4] Huerta, S (2003). "The mechanics of timbrel vaults: a historical outline," in Essays in the History of Mechanics. A. Becchi et al. (eds). Basel: Birkhäuser Verlag, 87-133.

[5] Huerta, S (2004). "Arcos, bóvedas y cúpulas. Geometría y equilibrio en el cálculo tradicional de estructuras de fábrica." Madrid: Instituto Juan de Herrera. Available at: http://ad.upm.es/

[6] Huerta, S, Fuentes, P, and López-Mozo, A (2010). "Informe sobre la estabilidad de las bóvedas y el sistema de contrarresto de la nave y el crucero de la Iglesia de La Peregrina (convento de San Francisco) en Sahagún.” Ayuntamiento de Sahagún. TRYCSA. Available at: http://ad.upm.es/ 